University of Nebraska - Lincoln

DigitalCommons@University of Nebraska - Lincoln

Agronomy \& Horticulture -- Faculty Publications

Agronomy and Horticulture Department

2009

\title{
Mapping and Confirmation of a New Allele at Rpp1 from Soybean PI 594538A Conferring RB Lesion-Type Resistance to Soybean Rust
}

\author{
Nanda Chakraborty \\ University of Illinois, nanda.chakraborty@syngenta.com \\ Joe Curley \\ University of Illinois \\ Reid D. Frederick \\ USDA-ARS, Foreign Disease-Weed Science Research Unit, reid.frederick@usda.gov \\ D. L. Hyten \\ Soybean Genomics and Improvement Laboratory, Beltsville, MD, david.hyten@unl.edu \\ Randall L. Nelson \\ University of Illinois, rlnelson@illinois.edu \\ Follow this and additional works at: https://digitalcommons.unl.edu/agronomyfacpub \\ ? next page for additional authors \\ Part of the Agricultural Science Commons, Agriculture Commons, Agronomy and Crop Sciences \\ Commons, Botany Commons, Horticulture Commons, Other Plant Sciences Commons, and the Plant \\ Biology Commons
}

Chakraborty, Nanda; Curley, Joe; Frederick, Reid D.; Hyten, D. L.; Nelson, Randall L.; Hartman, Glen L.; and Diers, Brian W., "Mapping and Confirmation of a New Allele at Rpp 1 from Soybean PI 594538A Conferring RB Lesion-Type Resistance to Soybean Rust" (2009). Agronomy \& Horticulture -- Faculty Publications. 789.

https://digitalcommons.unl.edu/agronomyfacpub/789

This Article is brought to you for free and open access by the Agronomy and Horticulture Department at DigitalCommons@University of Nebraska - Lincoln. It has been accepted for inclusion in Agronomy \& Horticulture -Faculty Publications by an authorized administrator of DigitalCommons@University of Nebraska - Lincoln. 
Authors

Nanda Chakraborty, Joe Curley, Reid D. Frederick, D. L. Hyten, Randall L. Nelson, Glen L. Hartman, and Brian W. Diers 


\title{
Mapping and Confirmation of a New Allele at $R p p 1$ from Soybean PI 594538A Conferring RB Lesion-Type Resistance to Soybean Rust
}

\author{
Nanda Chakraborty, Joe Curley, Reid D. Frederick, \\ David L. Hyten, Randall L. Nelson, Glen L. Hartman, and Brian W. Diers
}

\begin{abstract}
Soybean rust, caused by Phakopsora pachyrhizi (H. Sydow \& Sydow), is a destructive soybean [Glycine $\max$ (L.) Merr.] disease and identification of new resistance genes is essential for effective rust management. Our research objectives were to map and confirm the location of resistance gene(s) in PI 594538A using a population of $98 \mathrm{~F}_{3: 4}$ lines from a cross between PI 594538A (reddish-brown [RB] lesions) and the susceptible cultivar Loda (tan [TAN] lesions). The lines were inoculated with the $P$. pachyrhizi isolate ZM01-1 from Zimbabwe. The RB resistance in PI 594538A mapped on linkage group $\mathrm{G}$ as a single dominant gene. This gene is likely an allele of Rpp1 or a new closely linked gene because it mapped within $1 \mathrm{cM}$ of Rpp1 and ZM01-1 produced RB lesions on PI 594538A and TAN lesions on PI 200492, the original source of Rpp1. The mapping of the new Rpp1 allele, named Rpp1-b, was confirmed in a second population.
\end{abstract}

N. Chakraborty, J. Curley, and B.W. Diers, Dep. of Crop Sciences, Univ. of Illinois, Urbana, IL 61801; N. Chakraborty and J. Curley, current address: Syngenta Seeds, Inc., 317 330th St., Stanton, MN 55018; R.D. Frederick, USDA-ARS, Foreign Disease-Weed Science Research Unit, Fort Detrick, MD 21702; D.L. Hyten, USDA-ARS, Soybean Genomics and Improvement Lab., Beltsville, MD 20705; R.L. Nelson, and G.L. Hartman, USDA-ARS, Soybean/Maize Germplasm, Pathology, and Genetics Research Unit, Dep. of Crop Sciences, Univ. of Illinois, Urbana, IL 61801. Trade and manufacturers' names are necessary to report factually on available data; however, the USDA neither guarantees nor warrants the standard of the product, and the use of the name by USDA implies no approval of the product to the exclusion of others that may also be suitable. Received 16 June 2008. *Corresponding author (nanda.chakraborty@syngenta.com).

Abbreviations: BSL-3, Biosafety Level 3; FDWSRU, USDA-ARS Foreign Disease-Weed Science Research Unit; LG, linkage group; LOD, likelihood of odds; MG, maturity group; QTL, quantitative trait loci/locus; RB, reddish-brown; SBR, soybean rust; SNP, single nucleotide polymorphism; SSR, simple sequence repeat; TAN, tan.

Coybean Rust (SBR), caused by the obligate fungal pathogen P Phakopsora pachyrhizi (H. Sydow \& Sydow), was first reported in Japan in 1902 (Hennings, 1903). By 1934, the pathogen was reported in several other Asian countries and Australia (Bromfield and Hartwig, 1980). Since its first report in Uganda in 1996, P. pachyrhizi spread rapidly through several central and southern African countries (Akinsanmi and Ladipo, 2001; Pretorious et al., 2001; Levy, 2005). In South America, SBR was first detected in Paraguay in 2001 (Morel, 2001), and since then, P. pachyrhizi has been found in most of the soybean-producing regions of Brazil as well as in Argentina and Bolivia (Rossi, 2003; Yorinori et al., 2005).

Published in Crop Sci. 49:783-790 (2009).

doi: 10.2135/cropsci2008.06.0335

(C) Crop Science Society of America

677 S. Segoe Rd., Madison, WI 53711 USA

All rights reserved. No part of this periodical may be reproduced or transmitted in any form or by any means, electronic or mechanical, including photocopying, recording, or any information storage and retrieval system, without permission in writing from the publisher. Permission for printing and for reprinting the material contained herein has been obtained by the publisher. 
P. pachyrhizi was first found in the continental United States in November 2004 (Schneider et al., 2005). In 2007, the disease was reported in 334 U.S. counties and was found for the first time in one Canadian province and two Mexican states (Bradley, 2007). An early inoculum buildup in Texas and Louisiana, together with southerly winds in the central United States, are believed to be contributing factors in the spread of P. pachyrhizi farther north and west in 2007 compared with previous years (Pan et al., 2007).

In 2007, approximately 0.5 million ha of soybean were sprayed for SBR control in the United States (Giesler and Hershman, 2007). Although this accounts for only $3 \%$ of the total soybean acreage in the United States, there are concerns that if favorable weather patterns result in abundant inoculum early in the growing season, the Gulf Coast states might see a yearly occurrence of SBR (Giesler and Hershman, 2007).

Soybean rust has the potential to cause significant yield losses in the United States, as indicated by fungicide trials in Georgia and Florida that reported yield losses of 30 to $33 \%$ in untreated control plots (Kemerait et al., 2006; Mueller et al., 2009). In Brazil, the total yield loss due to SBR in the 2006-2007 growing season has been estimated to be equivalent to US $\$ 2.26$ billion (Neto et al., 2007), with an average of 2.3 fungicide applications required per season. Yield losses up to $80 \%$ have been reported due to severe outbreaks of SBR, which result in early leaf drop that inhibits pod set (Bromfield, 1984; Yang et al., 1991). Consistent economic losses in Brazil over the last several years due to severe SBR outbreaks have raised concerns about the potential impact of this disease in the United States, and this threat is creating an impetus to develop alternate disease management strategies such as host resistance. Soybean cultivars currently available commercially in the United States are all susceptible to SBR, and fungicide applications are the only current method to control the disease (Hartman et al., 2005), which results in significant production cost increases. Therefore, rust-resistant cultivars are needed to reduce fungicide costs and yield losses due to SBR.

Previous studies on host resistance to P. pachyrhizi have resulted in the identification of the four dominant, independently inherited major genes Rpp1, Rpp2, Rpp3, and Rpp 4 from PI 200492, PI 230970, PI 462312, and PI 459025B, respectively (Bromfield and Hartwig, 1980; McLean and Byth, 1980; Hartwig and Bromfield, 1983; Hartwig, 1986). Three of these genes (Rpp2-Rpp4) confer a resistant reddish-brown (RB)-colored lesion, as opposed to the susceptible tan (TAN)-colored lesion (Bromfield and Hartwig, 1980; Hartwig and Bromfield, 1983; Hartwig, 1986). The exception is Rpp1, which confers an immune response to some rust isolates (McLean and Byth, 1980; Bromfield, 1984; Bonde et al., 2006). These four major genes have been mapped on linkage groups (LGs) G, J, and C2 (Monteros et al., 2007; Silva et al., 2008; Hyten et al., 2009). An RB lesion-type resistance gene
Rpp?(Hyuuga) from the Japanese cultivar Hyuuga has been mapped by Monteros et al. (2007) to the same region on LG C2 as Rpp3 (Hyten et al., 2009). A fifth gene, Rpp5, was recently identified from PI 200456 and mapped on LG N (Calvo et al., 2008; Garcia et al., 2008). Additionally, 22 new sources of single major resistance genes have been reported from Brazil (Neto et al., 2007), and allelism tests may identify new genes or alleles. With the availability of the $7 \times$ sequence coverage of the soybean genome made possible by efforts of the USDOE Joint Genome Institute (Schmutz, 2008), Rpp1 has been fine-mapped to a $23-\mathrm{kb}$ region on scaffold 21 of LG G, and several single nucleotide polymorphisms (SNPs) close to this gene have been identified (D.L. Hyten, unpublished data, 2008).

Even though single genes are effective in other pathosystems, such as the Rcs 3 major gene that provides resistance to all known races of Cercospora sojina K. Hara (Missaoui et al., 2007), resistance in soybean lines carrying Rpp1 and Rpp 3 has already failed in the Brazilian state of Mato Grosso within $2 \mathrm{yr}$ of the establishment of the disease (Ribeiro et al., 2007). Single-gene resistance conferred by Rpp1, 2, 3, and 4 is race specific and can be overcome by U.S. as well as international $P$. pachyrhizi isolates (Miles et al., 2003; Hartman et al., 2005; Ribeiro et al., 2007). However, stacking quantitative trait loci (QTL) for resistance has been successful in managing disease caused by the rust species Puccinia striiformis Westend in barley (Hordeum vulgare L.) (Friedt and Ordon, 2007).

Many questions remain to be answered about the genetic variability of $P$. pachyrhizi, the durability of the major genes, and their associated fitness cost in the P. pachyrhizi population. P. pachyrhizi has a wide host range (Ono et al., 1992; Slaminko et al., 2008), and we currently lack information on the genetic variability of the founding pathogen population at the beginning of each soybean growing season as well as over consecutive years. Furthermore, there is a lack of a large set of soybean differentials to distinguish the P. pachyrhizi races. Previous research at the Asian Vegetable Research and Development Center in Taiwan using 10 differential hosts detected nine races (Hartman, 1995). Based on 24 simple sequence repeat (SSR) markers, Anderson et al. (2008) demonstrated a wide range of genetic variation among the six isolates collected from Alabama and Louisiana in 2004. Therefore, detecting additional sources of $\mathrm{SBR}$ resistance genes is imperative.

Introduced soybeans in maturity groups (MGs) 000 to $\mathrm{X}$ from the USDA Soybean Germplasm Collection were evaluated for SBR resistance at the seedling stage in 2004 at the USDA-ARS Foreign Disease-Weed Science Research Unit (FDWSRU) Biosafety Level 3 (BSL-3) Plant Pathogen Containment Facility (Miles et al., 2006). In the first preliminary test, PI 594538A was one of the 16,595 accessions screened for resistance to $P$. pachyrhizi with a mixture of four isolates collected in 2001 from Brazil, Paraguay, 
Thailand, and Zimbabwe. PI 594538A exhibited mixed lesions where both RB and TAN lesions occurred on the same leaf, with a disease severity score of 2 on a scale of 1 to 5 , where $1=$ no visible lesions and $5=$ prolific lesions (GRIN, 2008). PI 594538A was selected for retesting in a second greenhouse test at FDWSRU where it produced RB lesions when screened separately with field isolates from Brazil, Paraguay, Thailand, and Zimbabwe (M.R. Miles, G.L. Hartman, M.R. Bonde, S.E. Nester, D.K. Berner and R.D. Frederick, unpublished data, 2007). Subsequent greenhouse and field studies in 2005 and 2006 at the Univ. of Georgia demonstrated that with isolates from the southern United States, PI 594538A showed less resistance than with international isolates (H.R. Boerma, personal communication, 2006). However, in $2 \mathrm{yr}$ of field studies at the IITA, Ibadan, Nigeria, PI 594538A exhibited a very low diseased leaf area percentage of $0.1 \%$ with no sporulation (Twizeyimana et al., 2007). In a greenhouse study at IITA, PI 594538A showed a disease severity rating of 0.0 when screened separately with 116 isolates from Nigeria (Twizeyimana et al., 2009). This demonstrates that the resistance of PI 594538A can be effective over a wide array of SBR isolates and can be utilized as a new source of SBR resistance.

The objective of this research was to determine and confirm the mode of inheritance and map location of gene or genes underlying the RB lesion type-resistance in PI 594538A to the P. pachyrhizi isolate ZM01-1.

\section{MATERIALS AND METHODS Plant Material}

A population of $98 \mathrm{~F}_{3: 4}$ lines was derived from a cross between the MG IX accession PI 594538A from China, and the highyielding cultivar Loda (MG II). PI 594538A is a Chinese accession from Fujian province (GRIN, 2008), which exhibited RB lesions in SBR screenings using P. pachyrhizi isolate ZM01-1 performed at the FDWSRU (M.R. Miles, G.L. Hartman, M.R. Bonde, S.E. Nester, D.K. Berner, and R.D. Frederick, unpublished data, 2007). Loda is a soybean cultivar (Reg. no. CV-423, PI 614088) (Nickell et al., 2001) that is susceptible to the SBR pathogen P. pachyrhizi, producing TAN lesions. The $\mathrm{F}_{3: 4}$ lines were developed from the cross via single-seed descent using greenhouses at the Univ. of Illinois.

The PI 594538A confirmation population consisted of $99 \mathrm{~F}_{2: 3}$ lines that were developed by crossing an $\mathrm{F}_{1}$ plant from the PI 594538A $\times$ Loda cross with the susceptible MG II experimental line LD00-4970 (confirmation population). The pedigree of LD00-4970 is 'Maverick' $\times$ 'Dwight'. When inoculated with ZM01-1, TAN lesions are produced on LD00-4970.

\section{Greenhouse Inoculation and Phenotyping}

Both populations were inoculated at the USDA-ARS FDWSRU BSL-3 Plant Pathogen Containment Facility at Fort Detrick, MD (Melching et al., 1983), under the appropriate permit from the USDA Animal Plant Health Inspection Service. The populations were evaluated in 10 replicate randomized complete block design tests, with single plants from each line serving as replicates.
Border rows of susceptible soybean cultivar Williams 82 were placed at the periphery of the flats to reduce border effects. The experiments included known susceptible and resistant checks as well as the original sources of the SBR major genes Rpp1, 2, and 4. The source of Rpp3, PI 462312 was not available due to lack of seeds. The PI 594538A $\times$ Loda population was planted on 7 Feb. 2007, and the confirmation population was planted on 24 Oct. 2007. Both populations were planted by sowing two seeds per cell in 72 celled flats $(6 \times 12$ cells, 27 by $52 \mathrm{~cm})$ filled with Sunshine LC $_{1}$ mix (Sun Grow Horticultural Products, Belleview, WA). The plants were started in the greenhouses at the FDWSRU. Approximately 14 to $21 \mathrm{~d}$ after sowing, plants were thinned to one plant per cell and transported to the FDWSRU BSL-3 Containment Facility for inoculation.

The plants were inoculated with the $P$. pachyrhizi isolate ZM01-1, an isolate collected in Zimbabwe during 2001. Spores of the isolate were routinely increased on 'Williams' and stored under liquid nitrogen as previously described (Hyten et al., 2007). Inoculum was prepared using urediniospores stored in liquid nitrogen, heat shocked for $5 \mathrm{~min}$ at $40^{\circ} \mathrm{C}$, and rehydrated approximately $16 \mathrm{~h}$ over water in an enclosed Petri dish at room temperature. Spore suspensions were prepared in distilled water containing $0.01 \%$ Tween-20 and sprayed at the rate of 60,000 spores $\mathrm{mL}^{-1}$ with $40 \mathrm{~mL}$ flat ${ }^{-1}$ onto 14 - to 21 -d-old seedlings (V2 growth stage) with an atomizer at $138 \mathrm{kPa}$ (20 pounds force per square inch) (Hyten et al., 2007). Following inoculation, plants were incubated for approximately $16 \mathrm{~h}$ at $20^{\circ} \mathrm{C}$ in a dew chamber and later moved to a greenhouse maintained at $20^{\circ} \mathrm{C}$ for $14 \mathrm{~d}$ until symptoms were ready for rating.

First trifoliolate leaves were rated in both populations for susceptible TAN vs. resistant RB lesions. Disease severity based on symptom and lesion development was rated on a scale of 1 to 5 , where $1=$ no visible lesions, $2=$ light infection with few lesions present, $3=$ light to moderate infection, $4=$ moderate to severe infection, and $5=$ prolific lesions (Miles et al., 2006). The relative percentage of $\mathrm{RB}$ lesions sporulating was rated on a single-plant basis using a scale of 1 to 5 , where $1=$ no sporulation, $2=<25 \%$ of the lesions sporulating, $3=26$ to $50 \%$ of the lesions sporulating, $4=51$ to $75 \%$ of the lesions sporulating, and $5=76$ to $100 \%$ of the lesions sporulating. A plant was rated as immune when the unifoliolate and trifoliolate leaves were devoid of any visual symptoms (Bromfield and Hartwig, 1980).

\section{Genetic Marker Analysis}

Young trifoliolate leaf tissue was collected from 10 plants for each line grown in the greenhouses at the Univ. of Illinois. This tissue was freeze-dried and used to extract DNA according to Kabelka et al. (2005). For the PI 594538A $\times$ Loda population, the two parents were first screened to identify polymorphic SSR markers that map near Rpp1, 2, 3, 4, and Rpp?(Hyuuga). The whole population of $98 \mathrm{~F}_{3: 4}$ lines were then genotyped with the polymorphic SSR markers that have been mapped near these five known Rpp genes. Polymerase chain reaction products were obtained for both nonlabeled and fluorescently labeled SSR primers, followed by separation of nonlabeled products by nondenaturing polyacrylamide gel electrophoresis and for labeled products by ABI Prism 377 Genetic Analyzer (Applied Biosystems, Foster City, CA) (Cregan and Quigley, 1997; Wang et al., 2003). Additionally, a custom 1536 SNP GoldenGate assay was 
used to screen the two parents, PI 594538A and Loda, for polymorphisms and analyzed using the Illumina GoldenGate assay on the Illumina Beadstation 500 (Illumina, San Diego, CA) as described by Hyten et al. (2008). After initial mapping of an RB lesion-type gene from PI 594538A in the Rpp1 region on LG $\mathrm{G}$ in the PI 594538A $\times$ Loda population, the 5-cM region between Sct_187 and Sat_372 was surveyed to detect polymorphic SNPs in close proximity to Sat_064 where Rpp1 was originally mapped (Hyten et al., 2007). One SNP was identified and mapped in the PI 594538A $\times$ Loda population using a melting curve analysis with simple probes in a Roche LightCycler 480 System (Roche Applied Science, Indianapolis, IN) (H.R. Boerma, personal communication, 2008). An additional SNP was mapped in this region using a single-base extension assay on a Luminex 100 flow cytometer (Luminex Corporation, Austin, TX) (Missaoui et al., 2007).

For the confirmation population, the SSR and SNP markers that had been mapped in the original population on LG G were tested for polymorphism. Three SSR markers, Sat_117, Sat_372, and Sat_064, were then mapped.

\section{Statistical Analysis}

Data from both populations were analyzed using analysis of variance (SAS PROC GLM) (SAS Institute, Cary, NC), and the means for disease severity and sporulation within RB lesions were separated using Fisher's LSD test.
The SSR and SNP marker orders and distances were calculated with JoinMap software version 3.0 (Van Ooijen and Voorrips, 2001) using the Kosambi mapping function and a likelihood of odds (LOD) grouping threshold of 2.0. Reddishbrown vs. $\tan$ lesion phenotype was scored as a dominant trait for mapping in the PI 594538A $\times$ Loda and confirmation populations by grouping the RB and segregating lines together.

Genomic regions significantly associated with lesion number (disease severity) in both populations were detected using interval mapping and composite interval mapping in MapQTL software version 4.0 (Van Ooijen et al., 2002). A significance LOD threshold of 2.4 was used, which corresponds to an experiment-wise threshold of $P=0.05$ based on a permutation test.

\section{RESULTS AND DISCUSSION PI 594538A $\times$ Loda Population}

The $98 \mathrm{~F}_{3: 4}$ lines from the PI 594538A $\times$ Loda cross segregated 48 homozygous RB, 14 segregating, and 36 homozygous TAN lesion types when inoculated with the P. pachyrhizi ZM01-1 isolate. A chi-square test revealed that this did not fit the expected segregation of a single-gene ratio of 3/8 homozygous resistant, $1 / 4$ segregating, and $3 / 8$ homozygous susceptible in a population of $\mathrm{F}_{3: 4}$ lines (expected ratio 36.75:24.5:36.75) $(P=0.02)$. Fewer lines were found segregating for lesion types than expected, which was likely due to the large number of missing

Table 1. Greenhouse evaluations at Fort Detrick, MD, of soybean rust lesion type (reddish-brown [RB] or tan [TAN]), disease severity, and RB sporulation in PI594538A $\times$ Loda and LD00-4970 × (PI594538A $\times$ Loda) soybean populations.

\begin{tabular}{|c|c|c|c|c|c|c|c|}
\hline \multicolumn{4}{|c|}{ PI 594538A x Loda } & \multicolumn{4}{|c|}{ LD00-4970 × (PI 594538A $\times$ Loda $)$} \\
\hline Genotype & Lesion type & $\begin{array}{l}\text { Disease } \\
\text { severity }{ }^{\dagger}\end{array}$ & $\begin{array}{c}\text { RB } \\
\text { sporulation }\end{array}$ & Genotype & $\begin{array}{l}\text { Lesion } \\
\text { type }\end{array}$ & $\begin{array}{l}\text { Disease } \\
\text { severity }\end{array}$ & $\begin{array}{c}\mathrm{RB} \\
\text { sporulation }\end{array}$ \\
\hline Parents and population & & & & Parents and population & & & \\
\hline Loda & TAN & 2.9 & - & Loda & TAN & 2.4 & - \\
\hline \multirow[t]{2}{*}{ PI 594538A } & RB & 2.2 & 1.0 & PI 594538A & $\mathrm{RB}$ & 2.1 & 1.6 \\
\hline & & & & LD00-4970 & TAN & 3.4 & - \\
\hline RB lines mean $(n=62)^{\S}$ & $\mathrm{RB}$ & 2.3 & 1.4 & RB lines mean $(n=51)$ & $\mathrm{RB}$ & 2.5 & 1.8 \\
\hline $\mathrm{RB}$ lines range & $\mathrm{RB}$ & 2.0 to 3.1 & 1.0 to 3.2 & $\mathrm{RB}$ lines range & $\mathrm{RB}$ & 1.4 to 3.4 & 1.0 to 3.0 \\
\hline TAN lines mean $(n=36)$ & TAN & 3.4 & - & TAN lines mean $(n=26)$ & TAN & 3.0 & - \\
\hline TAN lines range & TAN & 2.9 to 3.8 & - & TAN lines range & TAN & 1.0 to 4.1 & - \\
\hline Population range & - & 2.0 to 3.8 & - & Population range & - & 1.0 to 4.1 & - \\
\hline Population mean & - & 2.8 & - & Population mean & - & 2.5 & - \\
\hline $\operatorname{LSD}(\alpha=0.05)$ & - & 0.41 & 0.45 & $\operatorname{LSD}(\alpha=0.05)$ & - & 0.57 & 0.30 \\
\hline Checks & & & & Checks & & & \\
\hline PI 200492 (Rpp1) & TAN & 3.7 & - & PI 200492 (Rpp1) & TAN & 2.2 & - \\
\hline L85-2378 (Rpp1) & TAN & 3.2 & - & L85-2378 (Rpp1) & TAN & 3.2 & - \\
\hline PI 230970 (Rpp2) & $\mathrm{RB}$ & 3.0 & 3.0 & PI 230970 (Rpp2) & $\mathrm{RB}$ & 3.0 & 3.1 \\
\hline PI 459025 B (Rpp4) & $-\pi$ & - & - & PI 459025 B (Rpp4) & $\mathrm{RB}$ & 3.6 & 3.6 \\
\hline Williams & TAN & 3.0 & - & Williams & TAN & 2.4 & - \\
\hline G01-PR33 (Rpp?Hyuuga) & TAN & 3.5 & - & G01-PR33 (Rpp?Hyuuga) & TAN & 3.8 & - \\
\hline
\end{tabular}

${ }^{\dagger}$ Disease severity on a scale of 1 to $5: 1=$ no visible lesions, $2=$ light infection with few lesions present, $3=$ light to moderate infection, $4=$ moderate to severe infection, and $5=$ prolific lesions.

FAmount of sporulation within RB lesions. Reddish-brown sporulation was rated on a scale of 1 to $5: 1=$ no sporulation, $2=<25 \%$ of the lesions sporulating, $3=26$ to $50 \%$ of the lesions sporulating, $4=51$ to $75 \%$ of the lesions sporulating, and $5=76$ to $100 \%$ of the lesions sporulating.

§Single plants with RB reactions were given sporulation ratings, whether these plants were from a homozygous RB line or from a line segregating for lesion type. The number indicates the sum of the number of homozygous RB and segregating lines.

TThis line was not included in the PI594538A x Loda population inoculation due to lack of seeds. 
plants within the lines, causing difficulty in distinguishing homozygous RB lines from segregating lines. When homozygous RB and segregating lines were combined, the data fitted a single dominant gene ratio of $5 / 8 \mathrm{RB}+$ segregating:3/8 TAN at $P=0.975$.

The parents of the population and sources of known rust resistance genes, except $R p p 3$ and $R p p 4$, were included in the test of the population with the ZM01-1 isolate. In this test, the PI 594538A parent produced RB lesions and the domestic parent Loda produced TAN lesions (Table 1). PI 200492, the original source of Rpp1, and L85-2378, the Williams 82 isoline containing the original Rpp1 allele (Hyten et al., 2007), and Hyuuga, the source of the Rpp?(Hyuuga) allele (Monteros et al., 2007), produced susceptible TAN lesions, whereas PI 230970, the source of Rpp2, produced RB lesions (Table 1). The reaction phenotypes of PI 200492 and PI 594538A were similar to the 2004 preliminary greenhouse inoculations using P. pachyrhizi isolate ZM01-1 (M.R. Miles, G.L. Hartman, M.R. Bonde, S.E. Nester, D.K. Berner and R.D. Frederick, unpublished data, 2007). A previous study by Bonde et al. (2006), reported an intermediate reaction on the Rpp2 source PI 230970, with the P. pachyrhizi ZM01-1, indicating a lesion type somewhere between TAN and RB. Our results demonstrated that ZM01-1 was able to overcome the resistance of the Rpp1 and Rpp?(Hyuuga) genes but produced a resistant $\mathrm{RB}$ reaction on the accessions with Rpp 2 and on PI 594538A.

All lines in the PI 594538A $\times$ Loda $\mathrm{F}_{3: 4}$ population with TAN lesions sporulated and only those single plants with $\mathrm{RB}$ reactions were given sporulation ratings, whether these plants were from a homozygous RB line or from a line segregating for lesion type. There was significant $(P<0.0001)$ variability in the population for sporulation ratings. The population mean value for RB sporulation on a scale of 1 to 5 was 1.4 (Table 1 ), and the population range was 1.0 to 3.2 (Table 1). Fourteen RB lines were given ratings of 1 , meaning that none of the lesions were sporulating (Table 1). Reddish-brown lines with no to low sporulation within lesions may be good sources of quantitative resistance because nonsporulating lines and lines with few sporulating lesions will have less inoculum buildup over the growing season, and, thereby, reduce the rate of disease development (Hartman et al., 2005). Although both PI 594538A and PI $230970(R p p 2)$ both produced RB lesions, PI 594538A had significantly less sporulation within the lesions (score of 1.0) than did PI 230970 (score of 3.0).

There was significant variability in the population for disease severity $(P<0.0001)$, which was also rated on a scale of 1 to 5 . The population mean was 2.8 and the range interval mapping. was 2.0 to 3.8. Among the lines that produced RB lesions, disease severity ranged from 2.0 to 3.1, with an average score of 2.3, whereas lines producing TAN lesions had a significantly higher average severity of 3.4 and a range of 2.9 to 3.8 (Table 1). Both parents developed light infections but differed significantly in disease severity, with severity ratings of 2.9 and 2.2 for Loda and PI 594538A, respectively (Table 1).

The allele conferring RB lesion type from PI 594538A was mapped to the same region on LG G as Rpp1 (Hyten et al., 2007) between the SNP markers BARC-01049500656 and BARC-014379-01337 (Fig. 1). The resistance allele from PI 594538A mapped $1.2 \mathrm{cM}$ above Sat_064, and Rpp1 mapped $0.4 \mathrm{cM}$ above it (Hyten et al., 2007). The marker order in the linkage map from our population and the Rpp1 mapping population is similar.

Disease severity was mapped as a QTL to the same position as the gene conferring RB lesion type. The disease severity QTL explained 76\% of the phenotypic variation, with $P<0.0001$ (Table 2). The LOD value for severity was 25 , exceeding the significance threshold LOD value of 2.4 as determined by the genome-wide permutation test.

\section{LD00-4970 × (PI 594538A $\times$ Loda) Confirmation Population}

Consistent with previous observations, the $P$. pachyrhizi isolate ZM01-1 produced TAN lesions on both susceptible parents, Loda and LD00-4970, and on PI 200492 and L852378, which has the Rpp1 allele from PI 200492. When inoculated with the ZM01-1 isolate, PI 230970 (Rpp2), PI 459025B (Rpp 4), and PI 594538A produced RB lesions (Table 1). The segregation ratio for lesion type among the $77 \mathrm{~F}_{2: 3}$ lines in the confirmation population was $17 \mathrm{RB}$, 34 segregating, and 26 TAN, which fit the expected segregation of 1:2:1 for a single gene in a population of $\mathrm{F}_{2: 3}$ lines $(P=0.21)$. Twenty-two lines of the original 99 were declared missing due to large numbers of missing plants

Table 2. Quantitative trait loci (QTL) for disease severity on linkage group G.

\begin{tabular}{|c|c|c|c|c|c|c|c|}
\hline \multirow{2}{*}{ Population } & \multirow{2}{*}{ Position } & \multirow{2}{*}{$\operatorname{LOD}^{\dagger}$} & \multirow{2}{*}{$R^{2 \ddagger}$} & \multirow{2}{*}{$P \S$} & \multicolumn{2}{|c|}{ Allele means" } & \multirow{2}{*}{ Locus } \\
\hline & & & & & $A$ & $B$ & \\
\hline & $\mathrm{cM}$ & & & & & & \\
\hline \multicolumn{8}{|l|}{ PI 594538A $\times$ Loda } \\
\hline \multirow[t]{3}{*}{ Disease severity } & 2.1 & 13.4 & 48 & 0.0001 & 3.2 & 2.4 & BARC-010495-00656 \\
\hline & 7.5 & 24.6 & 76 & 0.0001 & 3.4 & 2.3 & Rpp1-b \\
\hline & 7.7 & 23.2 & 73 & 0.0001 & 3.4 & 2.4 & BARC-014379-01337 \\
\hline \multicolumn{8}{|l|}{$\begin{array}{l}\text { LD00-4970 × } \\
(\text { PI 594538A × Loda) }\end{array}$} \\
\hline \multirow[t]{3}{*}{ Disease severity } & 5 & 17.0 & 61 & 0.0001 & 3.0 & 1.6 & Sat_064 \\
\hline & 5.7 & 17.5 & 62 & 0.0001 & 3.0 & 1.5 & Rpp1-b \\
\hline & 6 & 17.2 & 61 & 0.0001 & 3.0 & 1.6 & Sat_372 \\
\hline
\end{tabular}

tLikelihood of odds (LOD) score calculated by interval mapping.

${ }^{\prime} R^{2}$ representing the percentage of phenotypic variation explained by the QTL at the locus, calculated by

$\S P$ value calculated by nonparametric Kruskal-Wallis analysis.

"Phenotypic means of individuals carrying the indicated allele at the indicated locus. In both populations, the B allele is derived from PI 594538A, and the A allele is derived from the susceptible parent of the respective cross. 


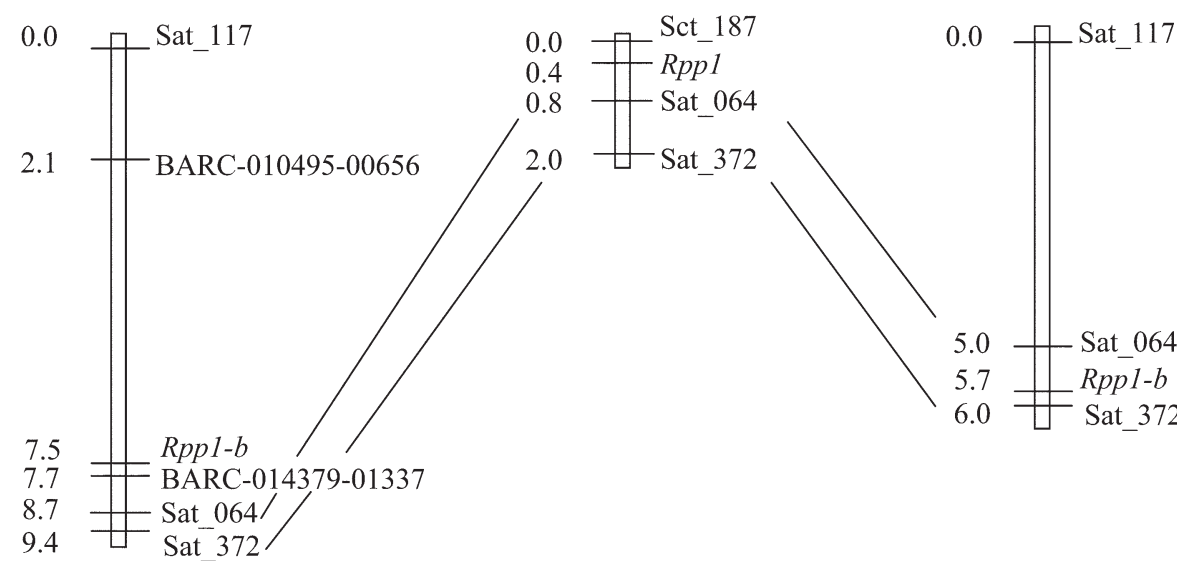

Figure 1. Genetic linkage map location of Rpp1-b conferring resistance to soybean rust on linkage group $G$ in the two mapping populations in this study, compared with the location of Rpp1. (a) Map location of Rpp1-b based on $98 \mathrm{~F}_{3: 4}$ lines from the PI 594538A (reddish-brown lesion) $\times$ Loda (tan lesion) population. The values to the left are distances (cM) generated using Kosambi's mapping function. (b) Map location of the Rpp1 locus in the 'Williams 82' $\times$ PI 200492 population with the distances (cM) as reported by Hyten et al. (2007). (c) Map location of Rpp1-b based on segregation of $77 \mathrm{~F}_{2: 3}$ lines in the confirmation population LD00-4970 (tan lesion) $\times$ (PI 594538A × Loda).

within the lines in which the seed did not germinate, which complicated distinguishing between homozygous RB and segregating lines.

LD00-4970 and PI 594538A were significantly different for disease severity, and significant variability for severity was observed among lines in the population $(P<0.0001)$. The population range for disease severity was 1.0 to 4.1 and with a population mean of 2.5 (Table 1). Lines with RB reactions had a mean disease severity score of 2.5 and a range of 1.4 to 3.4, and lines with susceptible TAN lesions had a higher mean severity score of 3.0 and a range of 1.0 to 4.1 (Table 1).

The lesions sporulated on all lines with TAN lesions. The sporulation ratings, assigned on a single-plant basis for RB plants in both homozygous and segregating RB lines, averaged 1.8 with a range of 1.0 to 3.0. Only one RB line had a sporulation rating of 1 (no sporulation), and seven lines had a sporulation score $<2.0$ (Table 1). The PI 594538A had a low sporulation score of 1.6 compared with the checks PI 230970 (Rpp2) and PI 459025B (Rpp4), which produced RB lesions but had higher sporulation scores of 3.1 and 3.6, respectively (Table 1).

The RB resistance allele from PI 594538A in the confirmation population was mapped as a qualitative trait to the same region on LG G as it was mapped in the PI 594538A × Loda population. In the confirmation population, the allele mapped within a 1.0-cM region flanked by Sat_064 and Sat_372 (Fig. 1), which is also close to the location of the Rpp1 locus (Hyten et al., 2007). The marker order on LG G created from the confirmation population conforms to those of the linkage maps based on the PI 594538A $\times$ Loda population, as well as the L85-2378 $\times$ Williams 82 population used to map the Rpp1 locus by Hyten et al. (2007), but the location of the resistance locus from PI 594538A relative to Sat_064 differed in the two populations in which it segregated. This type of order change in a small genetic interval is not unexpected, as it can easily be produced by small genotyping and phenotyping errors.

Disease severity was also mapped as a QTL on LG G (Table 2). The severity QTL had an LOD value of 17 , exceeding the genome-wide permutation significance threshold LOD value of 2.4, and explained $62 \%$ of the phenotypic variation. The LOD peak for disease severity mapped to Rpp1, where lesion type was mapped as a qualitative trait.

In this study, we mapped a major rust resistance gene conferring $\mathrm{RB}$ lesion type derived from PI 594538A and confirmed this mapping in a second population. The Soybean Genetics Committee has approved the name Rpp1-b for this allele. Although it is possible this is a new resistance locus tightly linked to Rpp1, the more likely conclusion is that this is a new allele at $R p p 1$ because i) we have mapped the allele from PI 594538A to within $1 \mathrm{cM}$ from the published location of Rpp1 (Hyten et al., 2007), and ii) in both experiments, the P. pachyrhizi isolate ZM01-1 produced TAN lesions on PI 200492 and L85-2378, which contain the original Rpp1 allele, but our new allele produced RB lesions.

In this study, we evaluated the entire PI 594538A $\times$ Loda population only using SSR markers linked to genomic regions known to carry Rpp genes and, therefore, we could potentially have missed mapping other rust resistance genes segregating in the population. However, the observed segregation ratios strongly support the existence of one major resistance gene segregating in the population, indicating that we have mapped the major resistance locus in the population.

Greenhouse experiments at Fort Detrick, MD, and Griffin, GA, and in the field at Attapulgus, GA, showed that PI 594538A had low resistance to U.S. isolates but exhibited RB lesion-type resistance to four international isolates (M.R. Miles, G.L. Hartman, M.R. Bonde, S.E. Nester, D.K. Berner, and R.D. Frederick, unpublished data, 2007; H.R. Boerma, personal communication, 2006). Field and greenhouse studies at IITA demonstrated that PI 594538A was resistant to field bulk isolates as well as 116 single spore isolates of $P$. pachyrhizi from Nigeria (Twizeyimana et al., 2007, 2009). Since Rpp1-b is a new allele of $R p p 1$ that provides a unique resistance reaction against $P$. pachyrhizi isolates that are not recognized by other SBR resistance alleles, incorporation of $R p p 1-b$ into soybean lines will 
expand resistance to these P. pachyrhizi isolates and, as the U.S. rust isolate population can change from year to year, the use of the Rpp1-b gene can provide protection against future pathogen populations. Several markers, including SSR s and SNPs, have been mapped within $1 \mathrm{cM}$ of Rpp1-b. Currently, soybean breeders are effectively utilizing these markers for marker-assisted selection of the Rpp1-b allele in the development of $P$. pachyrhizi-resistant cultivars with this gene and, in combination with other SBR genes, might lead to more durable resistance.

\section{Acknowledgments}

This research was supported by the United Soybean Board. We thank JoAnn Bowers for technical assistance with the plant propagation and inoculation experiments at the FDWSRU.

\section{References}

Akinsanmi, O.A., and J.L. Ladipo. 2001. First report of soybean rust (Phakopsora pachyrhizi) in Nigeria. Plant Dis. 85:97.

Anderson, S.J., C.L. Stone, M.L. Posada-Buitrago, J.L. Boore, B.A. Neelam, R.M. Stephens, D.G. Luster, R.D. Frederick, and K.F. Pedley. 2008. Development of simple sequence repeat markers for the soybean rust fungus, Phakopsora pachyrhizi. Mol. Ecol. Resour. 8:1310-1312.

Bonde, M.R., S.E. Nester, C.N. Austin, C.L. Stone, R.D. Frederick, G.L. Hartman, and M.R. Miles. 2006. Evaluation of virulence of Phakopsora pachyrhizi and P. meibomiae isolates. Plant Dis. 90:708-716.

Bradley, C.A. 2007. Overview of soybean rust in North America (United States \& Canada). Available at http://www.plantmanagementnetwork.org/infocenter/topic/soybeanrust/2007/ presentations/Bradley.pdf (verified 12 Mar. 2009).

Bromfield, K.R. 1984. Soybean rust. Monogr. 11. Am. Phytopathological Soc., St. Paul, MN.

Bromfield, K.R., and E.E. Hartwig. 1980. Resistance to soybean rust and mode of inheritance. Crop Sci. 20:254-255.

Calvo, E.S., R.A.S. Kiihl, A. Garcia, A. Harada, and D.M. Hiromoto. 2008. Two major recessive soybean genes conferring soybean rust resistance. Crop Sci. 48:1350-1354.

Cregan, P.B., and C.V. Quigley. 1997. Simple sequence repeat DNA marker analysis. p. 173-185. In G. Caetano-Anolles and P.M. Gresshoff (ed.) DNA markers: Protocols, applications and overviews. J. Wiley \& Sons, New York.

Friedt, W., and F. Ordon. 2007. Molecular markers for gene pyramiding and disease resistance breeding in barley. p. 81-101. In R.K. Varshney and R. Tuberosa (ed.) Genomics assisted crop improvement. Vol. 2: Genomics applications in crops. Springer, Dordrecht, the Netherlands.

Garcia, A., E.S. Calvo, R.A.S. Kiihl, A. Harada, D.M. Hiromoto, and L.G. Vieira. 2008. Molecular mapping of soybean rust (Phakopsora pachyrhizi) resistance genes: Discovery of a novel locus and alleles. Theor. Appl. Genet. 117:545-553.

Giesler, L.J., and D.E. Hershman. 2007. Overview and value of sentinel plots for 2007. Available at http://www.plantmanagementnetwork.org/infocenter/topic/soybeanrust/2007/ presentations/Giesler.pdf (verified 12 Mar. 2009).

GRIN. 2008. Germplasm Resources Information Network. Available at www.ars-grin.gov/npgs/index.html (verified 16 June 2008). Natl. Germplasm Resour. Lab., Beltsville, MD.
Hartman, G.L. 1995. Highlights of soybean rust research at the Asian Vegetable Research and Development Center. p. 19-28. In J.B. Sinclair and G.L. Hartman (ed.) Soybean Rust Workshop. 9-11 Aug. 1995. Natl. Soybean Res. Lab. Publ. 1. College of Agric., Consumer, and Environ. Sci., Urbana, IL.

Hartman, G.L., M.R. Miles, and R.D. Frederick. 2005. Breeding for resistance to soybean rust. Plant Dis. 89:664-666.

Hartwig, E.E. 1986. Identification of a fourth major gene conferring resistance to soybean rust. Crop Sci. 26:1135-1136.

Hartwig, E.E., and K.R. Bromfield. 1983. Relationships among three genes conferring specific resistance to rust in soybeans. Crop Sci. 23:237-239.

Hennings, P. 1903. Some new Japanese Uredinales. IV. Hedwigia (Suppl.):107-108.

Hyten, D.L., G.L. Hartman, R.L. Nelson, R.D. Frederick, V.C. Concibido, J.M. Narvel, and P.B. Cregan. 2007. Map location of the Rpp1 locus that confers resistance to soybean rust in soybean. Crop Sci. 47:837-838.

Hyten, D.L., J.R. Smith, R.D. Frederick, M.L. Tucker, Q. Song, and P.B. Cregan. 2009. Bulk segregate analysis using the GoldenGate assay to locate the Rpp3 locus that confers resistance to Phakopsora pachyrhizi (soybean rust) in soybean. Crop Sci. 49:265-271.

Hyten, D.L., Q. Song, I. Choi, M.S. Yoon, J.E. Specht, L.K. Matukumalli, R.L. Nelson, R.C. Shoemaker, N.D. Young, and P.B. Cregan. 2008. High-throughput genotyping with the GoldenGate assay in the complex genome of soybean. Theor. Appl. Genet. 116:945-952.

Kabelka, E.A., S.R. Carlson, and B.W. Diers. 2005. Localization of two loci that confer resistance to soybean cyst nematode from Glycine soja PI 468916. Crop Sci. 45:2473-2481.

Kemerait, R.C., L.E. Sconyers, P.H. Jost, and W.A. Mills. 2006. Evaluation of fungicides for control of Asian soybean rust in Attapulgus, Georgia, 2005. F\&N Tests 61:FC072.

Levy, C. 2005. Epidemiology and chemical control of soybean rust in southern Africa. Plant Dis. 89:669-674.

McLean, R., and D.E. Byth. 1980. Inheritance of resistance to rust (Phakopsora pachyrhizi) in soybean. Aust. J. Agric. Res. 31:951-956.

Melching, J.S., K.R. Bromfield, and C.H. Kingsolver. 1983. The plant pathogen containment facility at Frederick, Maryland. Plant Dis. 67:717-722.

Miles, M.R., R.D. Frederick, and G.L. Hartman. 2006. Evaluation of soybean germplasm for resistance to Phakopsora pachyrhizi. Plant Health Prog. doi:10.1094/PHP-2006-0104-01-RS.

Miles, M.R., G.L. Hartman, and R.D. Frederick. 2003. Soybean rust: Is the U.S. soybean crop at risk? Available at http://www. apsnet.org/online/feature/rust/ (verified 12 Mar. 2009). Am. Phytopathological Soc., St. Paul, MN.

Missaoui, A.M., B.K. Ha, D.V. Phillips, and H.R. Boerma. 2007. Single nucleotide polymorphism detection of the Rcs3 gene for resistance to frogeye leaf spot in soybean. Crop Sci. 47:1681-1690.

Monteros, M.J., A.M. Missaoui, D.V. Phillips, D.R. Walker, and H.R. Boerma. 2007. Mapping and confirmation of the 'Hyuuga' red-brown lesion resistance gene for Asian soybean rust. Crop Sci. 47:829-834.

Morel, W.P. 2001. Roya de la soja. Comunicado Técnico-Reporta Oficial, Serie Fitopatología 1, Junio de 2001. Ministerio de Agricultura y Ganadería, Subsecretaria de Agricultura, Dirección de Investigación Agrícola, Centro Regional de Investigación Agrícola-CRIA, Capitán Miranda, Itapua, Paraguay. 
Mueller, T.A., M.R. Miles, W. Morel, J.J. Marios, D.L. Wright, R.C. Kemerait, C. Levy, and G.L. Hartman. 2009. Effect of fungicide and timing of application on soybean rust severity and yield. Plant Dis. 93:243-248.

Neto, A.F., C.V. Godoy, and J.F.F. Toledo. 2007. Overview of soybean rust in Brazil. Available at http://www.plantmanagementnetwork.org/infocenter/topic/soybeanrust/2007/presentations/Neto1.pdf (verified 12 Mar. 2009).

Nickell, C.D., G.R. Noel, T.R. Cary, D.J. Thomas, and B.W. Diers. 2001. Registration of 'Loda' soybean. Crop Sci. 41:589-590.

Ono, Y., P. Buritica, and J.F. Hennen. 1992. Delimitation of Phakopsora, Physopella and Cretoelium and their species on Leguminosae. Mycol. Res. 96:825-850.

Pan, Z., L. Xue, X. Li, and X.B. Yang. 2007. Climate variability and soybean rust forecasts. Available at http://www.plantmanagementnetwork.org/infocenter/topic/soybeanrust/2007/ presentations/Pan.pdf (verified 12 Mar. 2009).

Pretorious, Z.A., R.J. Kloppers, and R.D. Frederick. 2001. First report of soybean rust in South Africa. Plant Dis. 85:1288.

Ribeiro, A.S., J. Ubirajara, V. Moreira, E.B. Pierozzi, B.F. Rachid, J.F.F. Toledo, C.A.A. Arias, R.M. Soares, and C.V. Godoy. 2007. Genetic control of Asian rust in soybean. Euphytica 157:15-25.

Rossi, R.L. 2003. First report of Phakopsora pachyrhizi, the causal organism of soybean rust in the province of Misiones, Argentina. Plant Dis. 87:102.

Schmutz, J.J. 2008. Progress on sequencing the soybean genome. Abstract W479. In Plant and Animal Genome XVI Conf., San Diego, CA. 12-16 Jan. 2008.

Schneider, R.W., C.A. Hollier, H.K. Whitman, M.E. Palm, J.M. McKenny, J.R. Hernández, L. Levy, and R. Devries-Paterson. 2005. First report of soybean rust caused by Phakopsora pachyrhizi in the continental United States. Plant Dis. 89:774.

Silva, D.C.G., N. Yamanaka, R.L. Brogin, C.A.A. Arias, A.L. Nepomuceno, A.D. Mauro, S.S. Pereira, L.M. Nogueira,
A.L.L. Passianotto, and R.V. Abdelnoor. 2008. Molecular mapping of two loci that confer resistance to Asian rust in soybean. Theor. Appl. Genet. 117:57-63.

Slaminko, T.L., M.R. Miles, R.D. Frederick, M.R. Bonde, and G.L. Hartman. 2008. New legume hosts of Phakopsora pachyrhizi based upon greenhouse evaluations. Plant Dis. 92:767-771.

Twizeyimana, M., P.S. Ojiambo, T. Ikotun, C. Paul, G.L. Hartman, and R. Bandyopadhyay. 2007. Comparison of field, greenhouse, and detached-leaf evaluations of soybean germplasm for resistance to Phakopsora pachyrhizi. Plant Dis. 91:1161-1169.

Twizeyimana, M., P.S. Ojiambo, K. Sonder, T. Ikotun, G.L. Hartman, and R. Bandyopadhyay. 2009. Pathogenic variation of Phakopsora pachyrhizi infecting soybean in Nigeria. Phytopathology 99:353-361.

Van Ooijen, J.W., M.P. Boer, R.C. Jansen, and C. Maliepaard. 2002. MapQTL 4.0, software for the calculation of QTL positions on genetic maps. Plant Res. Int., Wageningen, the Netherlands.

Van Ooijen, J.W., and R.E. Voorrips. 2001. JoinMap 3.0, software for the calculation of genetic linkage maps. Plant Res. Int., Wageningen, the Netherlands.

Wang, D., J. Shi, S.R. Carlson, P.B. Cregan, R.W. Ward, and B.W. Diers. 2003. A low-cost, high-throughput polyacrylamide gel electrophoresis system for genotyping with microsatellite DNA markers. Crop Sci. 43:1828-1832.

Yang, X.B., A.T. Tschanz, W.M. Dowler, and T.C. Wang. 1991. Development of yield loss models in relation to reductions of components of soybean infected with Phakopsora pachyrhizi. Phytopathology 81:1420-1426.

Yorinori, J.T., W.M. Paiva, R.D. Frederick, L.M. Costamilan, P.F. Bertagnoli, G.L. Hartman, C.V. Godoy, and J.J. Nunes. 2005. Epidemics of soybean rust (Phakopsora pachyrhizi) in Brazil and Paraguay from 2001 to 2003. Plant Dis. 89:675-677. 